\title{
HASONLÓSÁGOK ÉS KÜLÖNBSÉGEK MAGYARORSZÁG TERÜLETI FEJLETTSÉGÉBEN
}

\author{
Komarek Levente
}

\begin{abstract}
Absztrakt: Magyarország és az Európai Unió regionális politikájának egyik fő célkitűzése, hogy a területi különbségek mérséklődjenek. Ebből kifolyólag az elmaradottság felszámolása, a térségek fejlesztése és felzárkóztatása a tagországok kiemelt stratégiai feladata. A regionális politika alapelvein nyugvó fejlesztési támogatások hatékony felhasználásával az egyes térségek visszafordíthatatlan leszakadását megakadályozhatja, illetve felzárkóztatását elősegítheti. Az egyes térségek közötti fejlettségi különbségek kialakulását a természeti adottságok mellett a társadalmi-gazdasági tényezők is befolyásolják. Hazánkban a rendszerváltozás, majd pedig az Európai Unióhoz történő csatlakozást követően jelentős területi fejlettségbeni különbségek alakultak ki. Ebböl kifolyólag szükségessé válnak olyan elemzések, amelyek arra adnak választ, hogy milyen pozitív vagy negatív irányú változások következtek be az elmúlt években ezen a téren. Az elemzés Magyarország 20 területegységének (19 megye + Budapest) differenciált fejlődését és fejlettségi szintjének időbeni alakulását vizsgálja néhány aspektusból, amelyhez matematikai-statisztikai módszereket alkalmaztam, annak érdekében, hogy be tudjam mutatni az elmúlt évek változásának főbb tendenciáit.
\end{abstract}

\begin{abstract}
One of the main objectives of the regional policy of Hungary and of the European Union is to reduce regional disparities. For this reason, the elimination of backwardness, the development and the catching-up of the regions is a key strategic task of the member states. The effective use of development aid based on the principles of regional policy can help to prevent or re-invigorate the irreversible breakdown of certain areas. The development of differences between the various regions is influenced by socio-economic factors as well as natural conditions. In Hungary, after the change of regime and then the accession to the European Union, significant regional development differences emerged. For this reason, analyses are needed to find out what positive or negative changes have occurred in this field in recent years. The analysis examines the differentiated development of the 20 territorial units of Hungary (19 counties + Budapest) from a few aspects, applying mathematicalstatistical methods to be able to show the main trends of the change of recent years.
\end{abstract}

Kulcsszavak: egy före jutó bruttó hazai termék (GDP), beruházás, munkanélküliségi ráta, ipari termelés, $\mathrm{K}+\mathrm{F}$ ráfordítás, területi fejlettség, Magyarország

Keywords: gross domestic product (GDP) per capita, investment, unemployment rate, industrial production, $R \& D$ expenditure, territorial development, Hungary

\section{Bevezetés}

Az elmúlt évtizedekben, különösen a rendszerváltozás után, majd pedig az Európai Unióhoz történő csatlakozást követően, hazánkban is egyre nagyobb hangsúlyt kapott a területi fejlettséghez kapcsolódó elemzések. A tématerület jelentősége miatt, a regionális tudományok területén tevékenykedő számos kutató foglalkozott a fejlettség különböző aspektusaival. A területi fejlettséggel kapcsolatos vizsgálatok napjainkban is fontos szerepet játszanak a regionális kutatásokban (Abonyiné et. al., 2005, 2007, 2009).

A területi elemzések felértékelődésének eredményeképpen a fejlettség mérésének módszerei az elmúlt évtizedekben folyamatosan változtak. A módszerek változása a globális gazdasági és társadalmi folyamatokat, a hazai és nemzetközi trendeket, illetve a statisztikai adatbázisok fejlődését követte. A fejlettséghez kapcsolódó elemzések továbbra is a területi különbségekre, a fejlődés tényezőinek 
feltárására, illetve a területi differenciáltság csökkentésére tett javaslatokra fókuszál (Abonyiné et. al., 2010, 2017).

A területi fejlettséggel kapcsolatban az elmúlt évtizedekben jelentős mennyiségü tanulmány jelent meg hazánkban. Ugyanakkor elmondható, hogy a rendszerváltozást megelőző években is folyamatosan aktuális téma volt az egyes térségek fejlettségi szintjének alakulása, de az 1990-es évektől kezdődően a területi gazdaságitársadalmi kérdések még inkább a regionális tudományok fókuszába került (Abonyiné et. al., 2015).

Globalizálódó világunkban a gazdasági-társadalmi tényezők és a területi adottságok felértékelődésének köszönhetően a nemzetközi szakirodalomban a korábbi klasszikusnak mondható fejlődési elméletek háttérbe szorultak az újabb megközelítések megjelenésével. Mivel a hazai regionális kérdésekkel foglalkozó szakemberek folyamatosan figyelemmel kísérték a területi fejlődés vizsgálatához kapcsolósó nemzetközi eredményeket, ebből kifolyólag az új elemzési módszereket rövid idő alatt átvették és azt leggyakrabban hazai kontextusban alkalmazták a területi fejlettség különbségeinek bemutatására (Lados et. al., 2004).

A rendszerváltozás óta eltelt időszak alatt, a hazai regionális tudomány müvelői körében a regionális politika, a területfejlesztés, a településfejlesztés és a területi fejlettség kérdései mindinkább előtérbe kerültek (Horváth, 2004; Enyedi, 2000; Nemes Nagy, 2009). Napjainkban is a területi fejlettséghez kapcsolódó elméleti és empirikus kutatások nagy érdeklődésre tartanak számot a hazai „regionalisták” körében. Megállapítható, hogy a hazai (megyei, járási, települési) fejlettségi rangsorok elemzéséről és a fejlődési tendenciák értékeléséről szóló elemzések mellett egyre inkább elötérbe kerülnek a humán és ökológiai szempontokat figyelembe vevő területi versenyképesség, a belső (endogén) erőforrásokon nyugvó térségfejlesztés, vagy éppen az innovációs potenciálok és megújító képesség kérdéskörei (Ács J. et. al., 2000; Dőry et. al., 2005; Grosz et. al., 2005; Horváth, 2006; Lengyel, 2010; Varga, 2009).

A területi fejlettség elemzésére gyakran alkalmazott mutató az 1 före jutó bruttó hazai termék (GDP). Számos hazai kutató vizsgálta az 1 före jutó bruttó hazai termék (GDP) alapján a területi különbségeket, illetve hazánk megyéinek és régióinak fejlettségi sorrendjét (Bruckner et. al., 1999, 2003; Cserháti et. al., 2005; Farkasházi, 1998; Kása, 2006; Kovács, 2002; Nemes Nagy, 1995).

Az 1 főre jutó bruttó hazai termék (GDP) területi elemzéséhez kapcsolódóan, a hazai kutatók mélyreható elemzéseket végeztek az Európai Unió régióira, a keletközép-európai térségre, illetve a posztszocialista országok területi nivellálódására. Ezen mutatóhoz kapcsolódó elemzésekről megállapítható, hogy a módszertani vizsgálatok rendkívül változatosak. A különböző statisztikai elemzésektöl (átlag, szórás, relatív szórás), a Hoover-indexen át egészen a topológiai szemléltetésig terjedtek. Ezen kívül számos példa található korreláció- és regresszió-számításra is (Hahn, 2004; Horváth, 1998, 2004; Kiss et. al., 2006; Kuttor, 2012; Major et. al., 1999; Nemes Nagy, 2000, 2005; Nemes Nagy et. al., 2009; Szabó, 2008).

A területi különbségek bemutatására a hazai szakemberek gyakran alkalmazzák a beruházások területegységek szerinti alakulását, amelyet nagyon sok aspektusból 
vizsgálhatunk. Elemezhetjük a volumenének-, az ágazati-, a termékcsoport-, a termékszerkezetének-, a területi struktúrájának alakulását, a tőkeforrás-, a nagyság-, a szektor szerinti megoszlását is (Abonyiné et. al., 2011).

Számos elemzés foglalkozik a munkanélküliség területi különbségeivel. A kutatások arra a megállapításra jutottak, hogy a munkanélküliség területi különbségeire jelentős hatás gyakorolnak a térségek vállalkozási kapacitását meghatározó tényezők, mint például az infrastruktúra fejlettsége, a rendelkezésre álló munkaerő képzettségének színvonala. Az elmúlt években a területi fejlettség elemzéséhez a munkanélküliek számának alakulását és a munkanélküliségi rátát is gyakran alkalmazzák a regionális kérdésekkel foglalkozó szakemberek (Abonyiné et. al., 2011).

A hazai kutatások közül számos olyan elemzéssel találkozunk, amely a szekunder szektor területi kérdéseire fókuszált. Az elkészült elemzések arra törekednek, hogy az ipar területén használatos matematikai és matematikaistatisztikai módszerek széles skáláját alkalmazzák, annak érdekében, hogy részletes elemzéseket végezzenek és ezen keresztül alapos képet kapjanak a szektor területi különbségeiről és az elmúlt években bekövetkezett változások föbb irányáról, illetve mértékéről. Az elemzések részben az egyes felöl haladnak az általános felé (konkrét ipari ágazatok, alágazatok szerepének változása stb.), részben pedig általánosításból haladnak az egyes felé és megvizsgálják, hogy a nemzetgazdasági szinten érvényesülő problémák miként jelentkeznek különböző aspektusból területi szinten az ipar területén (Komarek, 2011, 2012a, 2012b, 2012c, 2013a, 2013b, 2013c, 2017, 2019; Krugman, 2003; Süli-Zakar et. al., 2012).

A $\mathrm{K}+\mathrm{F}$ ráfordítás mértéke jelentős pozitív hatást gyakorol egy térség fejlettségi szintjére. Napjainkban a gazdaság versenyképességének és a termelékenység növelésének egyik meghatározó feltétele a tudományos és technológiai területen nyújtott teljesítmény. A hazai szakemberek ezen a téren végzett elemzései azt igazolják, hogy a fejlett és gyorsan fejlődő országok (térségek) minél nagyobb hangsúlyt fektetnek a $\mathrm{K}+\mathrm{F}$ fejlesztésre, annál biztosabban tudják tartani és akár növelni gazdasági fölényüket.

\section{Anyag és módszer}

Az elemzéshez adatforrásként a Központi Statisztikai Hivatal (KSH) által rendelkezésre álló statisztikai adatokat használtam fel. Az adatokból olyan mutatókat képeztem, amelyek lehetővé tették hazánk fejlettségének időbeni és területi összehasonlító elemzését és a bekövetkezett változások föbb tendenciáinak bemutatását. Az elemzés a 2001 és 2016 közötti időszakot öleli fel, és az 1 főre jutó bruttó hazai termék (GDP), a beruházások, a munkanélküliségi ráta, az ipari termelés és az összes hazai $\mathrm{K}+\mathrm{F}$ ráfordítás területi alakulására fókuszál.

A rendszerváltozást követő években, majd pedig az Európai Unióhoz történő csatlakozását követően, hazánk területi fejlettségében változások következtek be. Ezek a változások szükségessé teszik olyan vizsgálatok és elemzések elvégzését, amelyek válaszokat adnak arra vonatkozóan, hogy a területi (megyei szintü) fejlettségben történtek-e pozitív vagy negatív irányú változások, illetve mely 
területegység (megye) súlya és szerepe növekedett vagy csökkent az elmúlt években ezen a téren. Ezen feltevések megválaszolására elemzésemhez matematikaistatisztikai módszereket alkalmaztam.Fejezet első bekezdése.

\section{Eredmények és értékelésük}

A területi fejlettség különbségeit számos statisztikai mutató segítségével jellemezhetjük. Ezen mutatók közül a leggyakrabban az 1 före jutó bruttó hazai termék (GDP) területi szintủ alakulását alkalmazzák. A bruttó hazai termék (GDP) volumenének és fajlagos értékeinek elemzésekor számos kritikai észrevétel vetődik fel ennek objektív voltára vonatkozóan. Ugyanakkor elmondható, hogy a térségek komplex fejlettségének meghatározásához ma sem ismeretesek jobb mutatók.

\section{1. táblázat: Az 1 före jutó bruttó hazai termék (GDP) magyarországi volumenének megyénkénti rangsora}

\begin{tabular}{|c|c|c|c|c|}
\hline Területegység/Megye & 2001 & 2006 & 2011 & 2016 \\
\hline Budapest & 1 & 1 & 1 & 1 \\
\hline Pest & 8 & 6 & 6 & 6 \\
\hline \multicolumn{5}{|l|}{ Közép-Magyarország } \\
\hline Fejér & 3 & 5 & 4 & 3 \\
\hline Komárom-Esztergom & 5 & 3 & 3 & 4 \\
\hline Veszprém & 7 & 10 & 11 & 8 \\
\hline \multicolumn{5}{|l|}{ Közép-Dunántúl } \\
\hline Győr-Moson-Sopron & 2 & 2 & 2 & 2 \\
\hline Vas & 4 & 4 & 5 & 5 \\
\hline Zala & 6 & 7 & 7 & 9 \\
\hline \multicolumn{5}{|l|}{ Nyugat-Dunántúl } \\
\hline Baranya & 13 & 11 & 14 & 16 \\
\hline Somogy & 17 & 17 & 16 & 17 \\
\hline Tolna & 10 & 15 & 9 & 11 \\
\hline \multicolumn{5}{|l|}{ Dél-Dunántúl } \\
\hline Borsod-Abaúj-Zemplén & 18 & 14 & 17 & 13 \\
\hline Heves & 12 & 12 & 13 & 12 \\
\hline Nógrád & 20 & 20 & 20 & 20 \\
\hline \multicolumn{5}{|l|}{ Észak-Magyarország } \\
\hline Hajdú-Bihar & 11 & 9 & 8 & 14 \\
\hline Jász-Nagykun-Szolnok & 15 & 16 & 15 & 15 \\
\hline Szabolcs-Szatmár-Bereg & 19 & 19 & 19 & 19 \\
\hline \multicolumn{5}{|l|}{ Észak-Alföld } \\
\hline Bács-Kiskun & 14 & 13 & 11 & 7 \\
\hline Békés & 16 & 18 & 18 & 18 \\
\hline Csongrád & 9 & 8 & 10 & 10 \\
\hline Dél-Alföld & & & & \\
\hline
\end{tabular}


A vizsgált időszakban megállapítható, hogy Budapest kitüntetett szerepe nemcsak állandósult, hanem mértéke kisebb megtorpanással, de dinamikusan növekedett. A range-arány (a két szélső érték között hányszoros a különbség) erőteljesen emelkedett,

$$
K=\frac{X_{\max }}{X_{\min }}
$$

ahol Budapest képezte a maximumot és Nógrád megye a minimumot $\left(\mathrm{K}_{2001}=3,58 ; \mathrm{K}_{2006}=4,36 ; \mathrm{K}_{2011}=4,83 ; \mathrm{K}_{2016}=4,65\right)$. Ez nem csak a főváros nagyon dinamikus fejlődéséből, hanem a leszakadó térségek lassú elöre mozdulásából is adódott.

A megyék közül a felső szélső értéket rendre Győr-Moson-Sopron megye alkotta. Az élenjáró bolyban mindig a Nyugat- és Észak-dunántúli megyék szerepeltek (Győr-Moson-Sopron, Vas, Fejér, Komárom-Esztergom) (1. táblázat).

Az alsó szélső értékü csoportok körében sem történt markáns változás. A vizsgált időszakban mindig Nógrád megye volt a sereghajtó. Nógrád megye mellett Borsod-Abaúj-Zemplén, Békés és Somogy megye volt a leginkább lemaradó az 1 főre jutó bruttó hazai termék (GDP) tekintetében.

Az alföldi hat megye, Bács-Kiskun kivételével az országos mezőnyben stagnált vagy pedig hátrébb csúszott. A legnagyobb visszaesés Hajdú-Bihar megyében szembetünő, amely 2011-ben még a 8. helyen volt, de 2016-ra a 14. helyre esett vissza.

Ha a range-arányt Budapest nélkül a 19 megyére vizsgáljuk, akkor is erőteljes differenciálódás állapítható meg. Ebben az esetben Győr-Moson-Sopron megye képezte a maximumot, míg Nógrád megye a minimumot $\left(\mathrm{K}_{2001}=2,05 ; \mathrm{K}_{2006}=2,28\right.$; $\left.\mathrm{K}_{2011}=2,70 ; \mathrm{K}_{2016}=3,13\right)$. Ebben az esetben is szembetűnő a két szélső érték közötti dinamikus növekedés.

Az 1 főre bruttó hazai termék (GDP) területi alakulásáról megállapítható, hogy a fejlett megyék egyre fejlettebbek lettek, míg a lemaradók mindinkább leszakadtak a vizsgált időszakban.

A területi fejlettség alakulásában az 1 főre jutó bruttó hazai termék (GDP) mellett fontos szerepe van a beruházásoknak is. A gazdasági növekedés, a fejlödés, a versenyképesség, az ágazati és a területi struktúra változás legfőbb forrása a beruházás. A beruházás multiplikátor hatása miatt nem közömbös annak nagysága, időbeni eloszlása és területi alakulása. Azok a térségek, amelyek hosszú távon kitüntetett helyzetet élveznek a befektetések tartós, dinamikus fejlődése, bővülése miatt, általában dinamikus térséggé válnak, míg ahová nem jut ezekből a fejlesztési forrásokból, vagy csak kevés, esetleg kevésbé hatékony, tartósan lemaradnak. Az is nagyon fontos, hogy a gazdaságpolitika, és (vagy) a gazdasági gyakorlat a legoptimálisabb, perspektivikus nemzetgazdasági ágakat preferálja.

A beruházások esetében is megállapítható, hogy a főváros vezető szerepe állandósult, a rang-arány pedig igen jelentős különbségeket mutat. Ebben az esetben a főváros képezte a maximumot és Nógrád megye Zala megyével váltakozva a 
minimumot $\quad\left(\mathrm{K}_{2001}=25,52 ; \quad \mathrm{K}_{2006}=24,15 ; \quad \mathrm{K}_{2011}=36,46 ; \quad \mathrm{K}_{2016}=17,10\right) . \quad \mathrm{Ha} \quad \mathrm{a}$ beruházások volumenét vizsgáljuk, megállapítható, hogy 2001-ben a beruházások 30\%-a a fővárosba koncentrálódott és 15 év távlatában ez a helyzet csak kis mértékben változott, mivel 2016-ban is a beruházások 27\%-a Budapestet részesítette elönybe.

\section{2. táblázat: A hazai beruházások volumenének megyénkénti rangsora}

\begin{tabular}{|c|c|c|c|c|}
\hline Területegység/Megye & 2001 & 2006 & 2011 & 2016 \\
\hline Budapest & 1 & 1 & 1 & 1 \\
\hline Pest & 2 & 2 & 3 & 2 \\
\hline \multicolumn{5}{|l|}{ Közép-Magyarország } \\
\hline Fejér & 5 & 6 & 6 & 4 \\
\hline Komárom-Esztergom & 11 & 5 & 13 & 6 \\
\hline Veszprém & 10 & 13 & 12 & 9 \\
\hline \multicolumn{5}{|l|}{ Közép-Dunántúl } \\
\hline Györ-Moson-Sopron & 3 & 7 & 2 & 3 \\
\hline Vas & 6 & 17 & 14 & 13 \\
\hline Zala & 13 & 16 & 19 & 20 \\
\hline \multicolumn{5}{|l|}{ Nyugat-Dunántúl } \\
\hline Baranya & 15 & 14 & 10 & 16 \\
\hline Somogy & 19 & 8 & 17 & 15 \\
\hline Tolna & 18 & 19 & 15 & 17 \\
\hline \multicolumn{5}{|l|}{ Dél-Dunántúl } \\
\hline Borsod-Abaúj-Zemplén & 4 & 4 & 5 & 5 \\
\hline Heves & 17 & 15 & 16 & 7 \\
\hline Nógrád & 20 & 20 & 20 & 18 \\
\hline \multicolumn{5}{|l|}{ Észak-Magyarország } \\
\hline Hajdú-Bihar & 7 & 3 & 7 & 11 \\
\hline Jász-Nagykun-Szolnok & 9 & 12 & 11 & 12 \\
\hline Szabolcs-Szatmár-Bereg & 8 & 9 & 9 & 10 \\
\hline \multicolumn{5}{|l|}{ Észak-Alföld } \\
\hline Bács-Kiskun & 12 & 10 & 4 & 8 \\
\hline Békés & 16 & 18 & 18 & 19 \\
\hline Csongrád & 14 & 11 & 8 & 14 \\
\hline Dél-Alföld & & & & \\
\hline
\end{tabular}

Forrás: saját szerkesztés KSH adatok alapján

A megyék felső szélső értékét egy év kivételével Pest megye alkotta. Az élenjáró között, mint ahogy az 1 före jutó bruttó hazai termék (GDP) esetében is láttuk, elsősorban Dunántúli megyék találhatók (pl. Győr-Moson-Sopron, Fejér). A Dunántúli megyék mellett a vizsgált időszakban jelentősebb beruházások valósultak meg Borsod-Abaúj-Zemplén megyében (2. táblázat). 
Az alsó szélső értékü csoportban sem történt ezen a téren jelentős változás. A vizsgált időszakban többnyire Nógrád megye volt a sereghajtó, amelyhez Békés, Tolna és Zala megye csatlakozott.

Az alföldi hat megyék közül a rangsorban csak Bács-Kiskun megye tudott előbbre lépni. A többi megyét elsősorban kisebb meglendülést követően a stagnálás, illetve egyeseket a visszaesés jellemzett a beruházásokat illetően.

Ha a rang-arányt a főváros nélkül a 19 megyére vizsgáljuk, akkor is jelentős területi különbségeket figyelhetünk meg. Ebben az esetben Pest és Győr-MosonSopron megye váltakozva a maximumot, míg Nógrád és Zala megye váltakozva a minimumot képezte $\left(\mathrm{K}_{2001}=8,99 ; \mathrm{K}_{2006}=9,03 ; \mathrm{K}_{2011}=14,05 ; \mathrm{K}_{2016}=5,98\right)$. Ebben az esetben is szembetünő a két szélső érték közötti olykor igen jelentős különbség.

Megvizsgáltam az 1 före jutó bruttó hazai termék (GDP) és a beruházások volumenének összefüggéseit is, amelynek eredményeképpen megállapítható, hogy a két mennyiségi ismérv között szoros pozitív korrelációs kapcsolat áll fenn $(\mathrm{r}=+8,3)$. Ebböl kifolyólag elmondható, hogy azokban a térségekben (megyékben), ahol magas a beruházás volumene ott általában magas az 1 főre jutó bruttó hazai termék (GDP) alakulása is.

A munkanélküliek számának alakulása szintén jelentős hatással van egy térség fejlettségi szintjére. Az elemzések azt igazolják, hogy az 1 före jutó bruttó hazai termék (GDP) és a beruházások területi rangsorai nagy hasonlóságot mutatnak a munkanélküliség alakulásának területi rangsoraival.

A munkanélküliség alakulásának jellemzésére gyakran alkalmazott mutató a munkanélküliségi ráta. Fontos megjegyezni, hogy a területi rangsorolás esetében a munkanélküliségi ráta „fordított mutatónak” számít, mivel a rangsor elején azok a területegységek találhatók, amelyekben a munkanélküliségi ráta a legnagyobb, míg a rangsor végén pedig azon területegységek, ahol a munkanélküliségi ráta a legalacsonyabb (3. táblázat).

A munkanélküliségi ráta esetében is megállapítható, hogy míg 2001-ben Zala, Veszprém, Csongrád, Győr-Moson-Sopron megye és a főváros volt a legkedvezőbb helyzetben, addig 2016-ra Győr-Moson-Sopron, Vas, Fejér, Veszprém és Pest megye került az élre. A legmagasabb munkanélküliségi arány 2001-ben Somogy, Szabolcs-Szatmár-Bereg, Borsod-Abaúj-Zemplén, Nógrád és Jász-NagykunSzolnok megyében volt. 2016-ra Szabolcs-Szatmár-Bereg, Nógrád, Borsod-AbaújZemplén megye mellé Hajdú-Bihar és Baranya megye sorakozott fel. A rang-arány nőtt, ami ismételten a mezőny széthúzódását mutatja $\left(K_{2001}=2,94 ; K_{2006}=2,98\right.$; $\left.\mathrm{K}_{2011}=2,94 ; \mathrm{K}_{2016}=5,65\right)$.

Az elemzés során górcső alá vettem az 1 főre jutó bruttó hazai termék (GDP), a beruházások és a munkanélküliségi ráta összefüggéseit. Megállapítást nyert, hogy az 1 före jutó bruttó hazai termék (GDP) és a munkanélküliségi ráta között negatív korrelációs kapcsolat áll fenn ( $\mathrm{r}=-0,32)$. Tehát ahol alacsonyabb az 1 före jutó bruttó hazai termék (GDP), ott általában magasabb a munkanélküliek aránya. Hasonlóan jártam el a beruházások és a munkanélküliségi ráta összefüggéseinek vizsgálata során is. Ebben az esetben is megállapítható, hogy a beruházások és a 
munkanélküliségi ráta között negatív korrelációs kapcsolat tapasztalható $(\mathrm{r}=-0,18)$. Tehát az alacsony beruházási kedv magasabb munkanélküliségi rátát eredményez.

3. táblázat: A hazai munkanélküliségi ráta alakulásának megyénkénti rangsora

\begin{tabular}{|c|c|c|c|c|}
\hline Területegység/Megye & 2001 & 2006 & 2011 & 2016 \\
\hline Budapest & 16 & 18 & 12 & 11 \\
\hline Pest & 15 & 17 & 17 & 16 \\
\hline \multicolumn{5}{|l|}{ Közép-Magyarország } \\
\hline Fejér & 13 & 19 & 13 & 18 \\
\hline Komárom-Esztergom & 14 & 12 & 18 & 15 \\
\hline Veszprém & 19 & 16 & 10 & 17 \\
\hline \multicolumn{5}{|l|}{ Közép-Dunántúl } \\
\hline Győr-Moson-Sopron & 17 & 20 & 20 & 20 \\
\hline Vas & 12 & 13 & 19 & 19 \\
\hline Zala & 20 & 15 & 14 & 14 \\
\hline \multicolumn{5}{|l|}{ Nyugat-Dunántúl } \\
\hline Baranya & 8 & 10 & 4 & 4 \\
\hline Somogy & 1 & 3 & 5 & 9 \\
\hline Tolna & 6 & 6 & 15 & 10 \\
\hline \multicolumn{5}{|l|}{ Dél-Dunántúl } \\
\hline Borsod-Abaúj-Zemplén & 3 & 2 & 3 & 5 \\
\hline Heves & 7 & 9 & 6 & 13 \\
\hline Nógrád & 4 & 4 & 2 & 3 \\
\hline \multicolumn{5}{|l|}{ Észak-Magyarország } \\
\hline Hajdú-Bihar & 9 & 8 & 7 & 2 \\
\hline Jász-Nagykun-Szolnok & 5 & 5 & 9 & 6 \\
\hline Szabolcs-Szatmár-Bereg & 2 & 1 & 1 & 1 \\
\hline \multicolumn{5}{|l|}{ Észak-Alföld } \\
\hline Bács-Kiskun & 10 & 7 & 11 & 7 \\
\hline Békés & 11 & 11 & 8 & 8 \\
\hline Csongrád & 18 & 14 & 16 & 12 \\
\hline
\end{tabular}

Forrás: saját szerkesztés KSH adatok alapján

Az ipar és ezen keresztuil az ipari termelés is hatást gyakorol egy térség fejlődésére. Az elmúlt évek során az Európai Unióban és hazánkban is egyre inkább előtérbe kerültek az ipar területi elhelyezkedésének kérdései. Napjainkban hazánk egyes térségeiben eltérö iparszerkezet alakult ki, egy-egy régióban különbözö iparágak váltak meghatározóvá. Az egyes iparágak területi elhelyezkedését és fejlődését számos társadalmi-gazdasági tényező (a termelés történelmi hagyományai, a tulajdonviszonyok, a munkaerő- és eszközellátottság, az erőforrások stb.) befolyásolja. A területileg differenciált iparszerkezet esetében az egyes 
térségekben változó jövedelmezőséggel, humán-erőforrás felhasználással, müszaki színvonallal, más-más kockázati tényezőkkel és piaci lehetőségekkel kell számolni. Az ipar területi és ágazati szerkezetének változása számos pozitív gazdasági folyamatot indukálhat (növekvő hatékonyság, versenyképesség, elmélyülő kooperáció), jelentős mértékben elősegítheti az adott térség és az egész nemzetgazdaság felemelkedését. A számos pozitív hatás mellett azonban negatív hatásokat is eredményezhet (pl. egyoldalú iparstruktúra, dekonjunktúra begyürüzése esetén mély válság, iparilag depressziós térségek kialakulása), amely rövidebbhosszabb időre visszavetheti az adott térség dinamikus fejlődését.

\section{4. táblázat: A hazai ipari termelés volumenének megyénkénti rangsora}

\begin{tabular}{|c|c|c|c|c|}
\hline Területegység/Megye & 2001 & 2006 & 2011 & 2016 \\
\hline Budapest & 1 & 2 & 1 & 2 \\
\hline Pest & 4 & 6 & 4 & 4 \\
\hline \multicolumn{5}{|l|}{ Közép-Magyarország } \\
\hline Fejér & 2 & 3 & 5 & 5 \\
\hline Komárom-Esztergom & 5 & 1 & 2 & 6 \\
\hline Veszprém & 11 & 11 & 14 & 11 \\
\hline \multicolumn{5}{|l|}{ Közép-Dunántúl } \\
\hline Győr-Moson-Sopron & 3 & 4 & 3 & 1 \\
\hline Vas & 7 & 8 & 10 & 9 \\
\hline Zala & 8 & 13 & 12 & 15 \\
\hline \multicolumn{5}{|l|}{ Nyugat-Dunántúl } \\
\hline Baranya & 18 & 18 & 19 & 19 \\
\hline Somogy & 16 & 17 & 16 & 18 \\
\hline Tolna & 19 & 19 & 18 & 16 \\
\hline \multicolumn{5}{|l|}{ Dél-Dunántúl } \\
\hline Borsod-Abaúj-Zemplén & 6 & 5 & 6 & 3 \\
\hline Heves & 13 & 10 & 8 & 10 \\
\hline Nógrád & 20 & 20 & 20 & 20 \\
\hline \multicolumn{5}{|l|}{ Észak-Magyarország } \\
\hline Hajdú-Bihar & 10 & 9 & 11 & 13 \\
\hline Jász-Nagykun-Szolnok & 9 & 7 & 7 & 8 \\
\hline Szabolcs-Szatmár-Bereg & 14 & 15 & 15 & 12 \\
\hline \multicolumn{5}{|l|}{ Észak-Alföld } \\
\hline Bács-Kiskun & 12 & 12 & 9 & 7 \\
\hline Békés & 17 & 16 & 17 & 17 \\
\hline Csongrád & 15 & 14 & 13 & 14 \\
\hline Dél-Alföld & & & & \\
\hline
\end{tabular}

Forrás: saját szerkesztés KSH adatok alapján

Az ipari termelés esetében megállapítható, hogy a vizsgált időszakban a fővárosnak meghatározó szerepe volt. A range-arány alakulásában a főváros, 
Komárom-Esztergom és Győr-Moson-Sopron megye képezte a maximumot, míg Nógrád megye a minimumot $\left(\mathrm{K}_{2001}=13,71 ; \mathrm{K}_{2006}=17,55 ; \mathrm{K}_{2011}=21,64 ; \mathrm{K}_{2016}=7,73\right)$.

A felső szélső értéket a főváros mellett Komárom-Esztergom, Győr-MosonSopron, Fejér és Pest megye képviselte. Az alsó szélső érték esetében pedig Nógrád, Tolna, Baranya és Békés megye volt a sereghajtó (4. táblázat).

Ha a range-arányt a főváros nélkül a 19 megyére vizsgáljuk, akkor megállapítható, hogy az egyes megyék között jelentős differenciáltság mutatkozik. Ebben az esetben Fejér, Komárom-Esztergom és Győr-Moson-Sopron megye képezte váltakozva a maximumot és Nógrád megye a minimumot $\left(K_{2001}=12,95\right.$; $\left.K_{2006}=17,97 ; K_{2011}=14,50 ; K_{2016}=9,40\right)$. Annak ellenére, hogy a két szélső érték közötti különbség az elmúlt 10 évben csökkenő tendenciát mutat, még mindig jelentős különbségek figyelhetők meg területi (megyei) szinten az ipari termelést illetően.

Az ipari termelést összevetettem az 1 före jutó bruttó hazai termék (GDP), a beruházások és a munkanélküliségi ráta alakulásával. Megállapítást nyert, hogy az 1 főre jutó bruttó hazai termék (GDP) és az ipari termelés között szoros pozitív korrelációs kapcsolat áll fenn $(\mathrm{r}=+0,77)$. Azaz azok a térségek, amelyekben jelentős az ipari termelés, ott általában magas az 1 före jutó bruttó hazai termék (GDP). Az ipari termelés és a beruházások összefüggéseit vizsgálva megállapítható, hogy a két mennyiségi ismérv között szintén szoros pozitív korrelációs kapcsolat tapasztalható $(\mathrm{r}=+0,68)$. Tehát azok a térségek, amelyekben jelentősebb beruházások (főleg ipari) valósulnak meg, ott magasabb az ipari termelés volumene. Az ipari termelés és a munkanélküliségi ráta közötti összefüggések esetében elmondható, hogy a két mennyiségi ismérv között negatív korrelációs kapcsolat áll fenn $(\mathrm{r}=-0,29)$. Ebből kifolyólag megállapítható, hogy ahol magasabb a munkanélküliségi ráta, ott általában alacsonyabb az ipari termelés volumene.

A $\mathrm{K}+\mathrm{F}$ ráfordítások hatékony felhasználása is segítheti egy térség dinamikus fejlődését. A vizsgált időszakban a $\mathrm{K}+\mathrm{F}$ ráfordítások növekvő tendenciát mutattak. 2001-ről 2016-ra a K+F ráfordítások több mint 4-szeresére növekedtek és meghaladták a 427 milliárd forintot.

A vizsgált időszakban megállapítható, hogy ezen a téren is Budapest meghatározó szerepe állandósult. A range-arány az elmúlt években csökkent, de még mindig jelentős különbségek figyelhetők meg a két szélső érték között. Nem meglepő, hogy Budapest képezte a maximumot és Nógrád, illetve Tolna megye váltakozva a minimumot $\quad\left(\mathrm{K}_{2001}=4750,55 ; \quad \mathrm{K}_{2006}=1014,53 ; \quad \mathrm{K}_{2011}=359,90\right.$; $K_{2016}=293$,25). Igaz, hogy a maximum és a minimum közötti rang-arány csökkent, de Budapest esetében a $\mathrm{K}+\mathrm{F}$ ráfordítások még mindig jelentős szerepet játszanak.

A megyék közül a felső szélső értéket folyamatosan Budapest alkotta. A rangsor elején elsősorban olyan megyék szerepelnek, amelyek esetében jelentősebb felsőoktatási intézmények is vannak (Csongrád, Hajdú-Bihar, Győr-Moson-Sopron, Pest) (5. táblázat).

Az alsó szélső érték esetében egy év kivételével Tolna megye volt a sereghajtó. Tolna megye mellett Nógrád, Békés és Zala megye volt a leginkább lemaradó ezen a téren. 
Ha a rang-arányt Budapest nélkül vizsgáljuk a 19 megyére, akkor is megállapítható, hogy jelentős differenciálódás tapasztalható. Ebben az esetben Hajdú-Bihar megye képezte a maximumot és Tolna, valamint Nógrád megye váltakozva a minimumot $\left(\mathrm{K}_{2001}=390,75 ; \mathrm{K}_{2006}=94,77 ; \mathrm{K}_{2011}=38,01 ; \mathrm{K}_{2016}=26,08\right)$. Ebben az esetben is elmondható, hogy a vizsgált időszakban csökkent a maximum és minimum közötti arány, de még mindig jelentős különbségek tapasztalhatók.

\section{5. táblázat: Az összes hazai $\mathbf{K}+\mathbf{F}$ ráfordítás volumenének megyénkénti} rangsora

\begin{tabular}{|c|c|c|c|c|}
\hline Területegység/Megye & 2001 & 2006 & 2011 & 2016 \\
\hline Budapest & 1 & 1 & 1 & 1 \\
\hline Pest & 5 & 4 & 5 & 5 \\
\hline \multicolumn{5}{|l|}{ Közép-Magyarország } \\
\hline Fejér & 8 & 8 & 10 & 8 \\
\hline Komárom-Esztergom & 16 & 16 & 14 & 12 \\
\hline Veszprém & 7 & 7 & 6 & 4 \\
\hline \multicolumn{5}{|l|}{ Közép-Dunántúl } \\
\hline Győr-Moson-Sopron & 4 & 5 & 4 & 6 \\
\hline Vas & 18 & 14 & 11 & 9 \\
\hline Zala & 17 & 18 & 17 & 19 \\
\hline \multicolumn{5}{|l|}{ Nyugat-Dunántúl } \\
\hline Baranya & 6 & 6 & 7 & 11 \\
\hline Somogy & 13 & 17 & 15 & 16 \\
\hline Tolna & 20 & 19 & 20 & 20 \\
\hline \multicolumn{5}{|l|}{ Dél-Dunántúl } \\
\hline Borsod-Abaúj-Zemplén & 9 & 11 & 9 & 10 \\
\hline Heves & 15 & 10 & 12 & 14 \\
\hline Nógrád & 19 & 20 & 19 & 17 \\
\hline \multicolumn{5}{|l|}{ Észak-Magyarország } \\
\hline Hajdú-Bihar & 3 & 2 & 2 & 2 \\
\hline Jász-Nagykun-Szolnok & 12 & 12 & 13 & 13 \\
\hline Szabolcs-Szatmár-Bereg & 14 & 13 & 16 & 15 \\
\hline \multicolumn{5}{|l|}{ Észak-Alföld } \\
\hline Bács-Kiskun & 10 & 10 & 8 & 7 \\
\hline Békés & 11 & 15 & 18 & 18 \\
\hline Csongrád & 2 & 3 & 3 & 3 \\
\hline Dél-Alföld & & & & \\
\hline
\end{tabular}

Forrás: saját szerkesztés KSH adatok alapján

A K+F ráfordításokat az 1 főre jutó bruttó hazai termék (GDP), a beruházások és az ipari termelés volumenének alakulásával. Megállapítást nyert, hogy az 1 före jutó bruttó hazai termék (GDP) és a $\mathrm{K}+\mathrm{F}$ ráfordítások között szoros pozitív korrelációs kapcsolat áll fenn $(\mathrm{r}=+0,79)$. Azaz azok a térségek, amelyekben a $\mathrm{K}+\mathrm{F}$ 
ráfordítások jelentősebb szerepet kapnak, ott általában magasabb az 1 före jutó bruttó hazai termék (GDP). A K+F ráfordítások és a beruházások összefüggéseit vizsgálva megállapítható, hogy a két mennyiségi ismérv között igen szoros pozitív korrelációs kapcsolat tapasztalható $(\mathrm{r}=+0,93)$. Tehát azok a térségek, amelyekben jelentősebb beruházások valósulnak meg, ott magasabb a $\mathrm{K}+\mathrm{F}$ ráfordítások volumene. Az ipari termelés és a $\mathrm{K}+\mathrm{F}$ ráfordítások közötti összefüggések esetében elmondható, hogy a két mennyiségi ismérv között közepes pozitív korrelációs kapcsolat áll fenn $(\mathrm{r}=+0,52)$. Ebből kifolyólag megállapítható, hogy ahol magasabb az ipari termelés ott általában magasabb a $\mathrm{K}+\mathrm{F}$ ráfordítás is.

\section{Következtetések és javaslatok}

Az elmúlt több mint 15 év során hazánkban, megyei szinten a fejlettségbeni különbségek állandósultak. A készült elemzés alapján megállapítható, hogy a fejlettségben előkelő helyet elfoglaló - elsősorban Nyugat- és Közép-dunántúli megyék, illetve a föváros szerepe továbbra is meghatározó maradt. Ezzel szemben főleg az Észak-magyarországi és az alföldi megyék többségénél pedig a lemaradás, valamint a leszakadás érvényesült. A vizsgált ismérvek a területi fejlettség meghatározásában fontos szerepet játszanak, egymásra hatással vannak. Azon térségekben, ahol jelentős a beruházási kedv, magasabb az ipari termelés, alacsonyabb a munkanélküliségi ráta, eredményesebb a $\mathrm{K}+\mathrm{F}$ ráfordítás, ott általában magasabb az 1 före jutó bruttó hazai termék (GDP) alakulása.

Megállapítható, hogy a beruházásoknak valamely térség jelen-, illetve jövőbeni fejlődésére nagyon nagy a hatásuk. Ezért, ha a területi fejlettségben az egyes térségek a kiegyenlítődésre törekszenek, akkor a tökebefektetésekre különösen oda kell figyelniük. Az elmaradottabb térségek felzárkóztatása csak intenzívebb fejlesztési források biztosításával lehetséges. Ha a beruházás területileg egyenlőtlenül valósul meg, azok a térségek, amelyek hosszú távon kitüntetett helyzetet élveznek a befektetések tartós bővülése miatt, általában dinamikus térséggé válnak, míg ahová kevesebb fejlesztési forrás jut, vagy kevésbé hatékony, tartósan lemaradnak. Krugman úgy fogalmaz,43 hogy a gazdaság térbeli koncentrációjának és szétterülésének centripetális és centrifugális eröi között kötélhúzás van. Ennek az ellentétes irányú fejlődésnek vannak nyertesei és vesztesei. Az elkövetkezö évek nyertesei közé sorolhatjuk a dunántúli megyék mellett az alföldi megyék közül BácsKiskun és Hajdú-Bihar megyét. Előbbi a Mercedes (Kecskemét), utóbbi pedig a BMW és a Continental (Debrecen) több milliárd forintos beruházásainak köszönhetően. A megvalósult és a hamarosan megvalósuló új beruházások elösegíthetik az adott térségek dinamikus fejlődését.

Napjainkban fontos kulcskérdés az ipari termelés alakulása és struktúrájának racionalizálása. Hazánk gazdasági „nyitottsága” és így a nemzetközi munkamegosztás alakulása igen nagy hatással volt/van az egyes térségek (megyék) fejlődésére és sok esetben az ipar területi specializációjának irányára is. Több évtizeden keresztül a térségek közötti munkamegosztásra jellemző volt, hogy általában a fejlett térségek, különböző feldolgozóipari termékeket értékesítettek a kevésbé fejlett térségeknek, elsősorban mezőgazdasági termékekért cserébe. A 
rendszerváltozást követő években és napjainkban, az egyes térségekben (régiókban, megyékben) különböző iparágak kerültek előtérbe, váltak meghatározóvá. Ebből kifolyólag a fejlett és a kevésbé fejlett térségek között újszerủ munkamegosztás kezd kirajzolódni. A globális gazdasági folyamatok miatt megváltozott a területi munkamegosztás jellege és az ezen a téren jelentkező új kihívások hatással lesznek a területi specializáció alakulására is. A hazai iparban a közelmúltban megvalósult és a jövőben megvalósuló újabb nagyvolumenü termelő beruházások új helyzetet teremthetnek iparunk területi specializációjában és ágazati koncentrációjában. Az iparnak mind a területi, mind pedig a szerkezeti átalakulása folyamatos fejlödés eredménye. Ezért a jelenlegi ipar szerkezeti és területi változásai (a mindenkori piaci viszonyok függvényében) a jövőben várhatóan tovább folytatódnak.

Összességében elmondható, hogy a vizsgált időszak alatt is a kiegyenlítődés helyett a területi differenciálódás olykor tovább növekedett. Az elmúlt években, de különösen az EU-s csatlakozásunk óta felhasznált fejlesztési forrásaink lehetővé tettek volna némi területi felzárkózást. A fejlesztési forrásaink racionálisabb felhasználásával, az innovatívabb, a versenyképesebb termelö ágazatok megakadályozhatták volna az térségek tendenciózus leszakadását, amelynek eredményeképpen a fejlett és a fejlettlen térségek közötti különbségek csökkenhettek volna. Ezzel szemben a fejlett térségek egyre fejlettebbé válnak, ugyanakkor a fejletlenek leszakadása kisebb ingadozással, de sajnos tovább folytatódik.

\section{Irodalomjegyzék}

Abonyiné Palotás J., Komarek L. (2005): Jegyzet Magyarország társadalomföldrajza tanulmányozásához. JATEPress Kiadó, Szeged.

Abonyiné Palotás J., Komarek L. (2007): Dél-Alföld gazdasági helyzete és a kilábalás lehetőségei. Területi Statisztika, 10 (47) (6) 586-594.

Abonyiné Palotás J., Komarek L. (2009): Gondolatok a Duna szűkebb, illetve tágabb környezetében kifejtett térségfejlesztő hatásáról - A Duna-menti kistérségek összehasonlító vizsgálata. Comitatus - Önkormányzati Szemle, 13 (6): 69-77.

Abonyiné Palotás J., Komarek L. (2010): A Duna menti kistérségek összehasonlító vizsgálata (A Duna, mint az ország dinamizáló tengelye). In: Veres L. (szerk.): Duna Térségi Kohézió: II. Interregionális Nemzetközi Tudományos Konferencia. Cikos Group, Subotica. 385-393 .

Abonyiné Palotás J., Komarek L. (2011): Összehasonlító vizsgálatok az ipari beruházások ágazati és területi szerkezetének alakulásáról. Comitatus - Önkormányzati Szemle, 21 (9): 25-33.

Abonyiné Palotás J., Komarek L. (2015): Changes in hungarian spatial differences during the past two decades. Review on Agriculture and Rural Development, 4 (1-2): 29-37.

Abonyiné Palotás J., Komarek L. (2017): Területi egyenlőtlenségeink alakulása. In: András I., Rajcsányi-Molnár M. (szerk.): East-west cohesion: strategical study volumes. Cikos Group, Subotica. 18-26.

Ács J. Z., Varga A. (2000): Térbeliség, endogén növekedés és innováció. Tér és Társadalom, 14 (4): 23-38.

Bruckner Jné., Farkasházi Lné., Gether Iné. (1999): A bruttó hazai termék területi megoszlása 1997ben. Területi Statisztika, 2 (39) (3): 235-243.

Bruckner Jné., Gether Iné. (2003): A területi GDP-számítás helyzete, a továbbfejlesztés feladatai. Területi Statisztika, 6 (43) (4): 323-332.

Cserháti I., Dobosi E., Molnár Zs. (2005): Regionális fejlettség és tőkevonzási képesség. Területi Statisztika, 8 (45) (1): 15-32. 
Dőry T., Rechnitzer J. (2005): A regionális fejlődés és az innováció. In: Grosz A. - Rechnitzer J. (szerk.): Régiók és nagyvárosok innovációs potenciálja Magyarországon. MTA RKK, PécsGyör. 23-43.

Enyedi Gy. (2000): Globalizáció és magyar területi fejlődés. Tér és Társadalom, 14 (1) 1-10.

Farkasházi Lné. (1998): A bruttó hazai termék (GDP) területi megoszlása. Területi Statisztika, 1 (38) (1): $3-11$.

Grosz A., Rechnitzer J. (szerk.) (2005): Régiók és nagyvárosok innovációs potenciálja Magyarországon. MTA RKK, Pécs-Györ.

Hahn Cs. (2004): A térségi fejlődést befolyásoló tényezők. Területi Statisztika, 7 (44) (6) 544-563.

Horváth Gy. (1998): Az átmenet regionális hatásai Kelet-Közép-Európában. Területi Statisztika, 1 (38) (4): 295-318.

Horváth Gy. (2004): Regionális egyenlőtlenségek Európában. Magyar Tudomány, 49 (111) (9): 962977.

Horváth Gy. (szerk.) (2006): Régiók és települések versenyképessége. MTA RKK, Pécs.

Kása K. (2006): A gazdasági versenyképesség területi különbségei Magyarországon. Területi Statisztika, 9 (46) (4): 428-434.

Kiss J. P., Németh N. (2006): Fejlettség és egyenlötlenségek: Magyarország megyéinek és kistérségeinek esete. Budapesti Munkagazdaságtani Füzetek 8. MTA KTI, Budapest.

Komarek L. (2011): A magyar ipar főbb sajátosságai az abszolút specializáció tükrében. Jelenkori Társadalmi és Gazdasági Folyamatok, 6 (1-2): 28-34 .

Komarek L. (2012a): The absolute specialisation of Hungarian industry with regard to regional export. Review on Agriculture and Rural Development, 1 (1): 50-55.

Komarek L. (2012b): A magyar ipar struktúrájának és területi specializációjának főbb vonásai. $A$ földrajz tanítása - Módszertani folyóirat, 20 (1): 28-35.

Komarek L. (2012c): A hazai ipar specializációja és koncentrációja a humánerőforrás tükrében. Humánpolitikai Szemle, 23 (2): 3-15.

Komarek L. (2013a): Changes of human resource concentration and specialisation in hungarian industry. Review on Agriculture and Rural Development, 2 (1): 91-97.

Komarek L. (2013b): Structural Changes in the Foreign Trade of Hungary and the European Union. Review on Agriculture and Rural Development. 2 (2): 521-529.

Komarek L. (2013c): A few regional specialization issues of Hungary. In: Veres L. (szerk.): Regionális földrajzi tanulmányok: Abonyiné Dr. Palotás Jolán 70. születésnapja tiszteletére. Egyesület Közép-Európa Kutatására, Szeged. 47-60.

Komarek L. (2017): A magyar ipar makroszintü specializációja: Területi és ágazati struktúra. GlobEdit, Saarbrücken.

Komarek L. (2019): Territorial differentiation of the development of Hungary. Romanian Journal of Regional Science, 13 (1): 15-34.

Kovács T. (2002): A területi fejlettségi különbségek alakulása Magyarországon. Területi Statisztika, 5 (42) (6): 506-517.

Krugman P. (2003): Földrajzés kereskedelem. Nemzeti Tankönyvkiadó, Budapest.

Kuttor D. (2012): Kelet-Közép-Európa változó gazdasági térszerkezetének modellezése. Miskolci Egyetem Kiadó, Miskolc.

Lados M., Rechnitzer J. (2004): A területi stratégiáktól a monitoringig. Dialóg Campus Kiadó, PécsBudapest.

Lengyel I. (2010): Regionális gazdaságfejlesztés. Versenyképesség, klaszterek és alulról szervezödő stratégiák. Akadémiai Kiadó, Budapest.

Nemes Nagy J. (1995): A GDP regionális számbavétele. In: Probáld F. (szerk.): Pro Geographia Humana. ELTE Eötvös Kiadó, Budapest. 99-118.

Major K., Nemes Nagy J. (1999): Területi jövedelemegyenlötlenségek a kilencvenes években. Statisztikai Szemle, 77 (6): 397-421.

Nemes Nagy J. (2000): A humán erőforrások regionális differenciáltsága a kilencvenes években. In: Fóti K. (szerk.): Az emberi erőforrások jellemzői Magyarországon 1999. UNDP-MTA VKI, Budapest. 61-70. 
Nemes Nagy J. (2005): Fordulatra várva - A regionális egyenlőtlenségek hullámai. In: Dövényi Z. Schweitzer F. (szerk.): A földrajz dimenziói. MTA FKI, Budapest. 141-158.

Nemes Nagy J. (2009): Terek, helyek, régiók. A regionális tudomány alapjai. Akadémiai Kiadó, Budapest.

Nemes Nagy J., Tagai G. (2009): Területi egyenlőtlenségek, térszerkezeti determinációk. Területi Statisztika, 12 (49) (2): 152-169.

Süli-Zakar I., Komarek L. (2012): A Kárpát-medence élelmiszer-gazdasága. In. Dövényi Z. (szerk.): A Kárpát-medence földrajza. Akadémiai Kiadó, Budapest. 562-602.

Szabó P. (2008): A gazdasági fejlettség egyenlőtlensége az Európai Unió különböző területi szintjein. Területi Statisztika. 11 (48) (6): 687-699.

Varga A. (2009): Térszerkezet és gazdasági növekedés. Akadémiai Kiadó, Budapest. 